\title{
Pasienter med ARDS i mageleie
}

\begin{abstract}
ARDS forårsaker alvorlig hypoksisk respirasjonssvikt. Mageleie kan bidra til gunstige fysiologiske effekter og kan være et behandlingsalternativ ved ARDS.
\end{abstract}

Hilde Marie Nilsen

Intensivsykepleier

Sykehuset Østfold

Monica Rosnes

intensivsykepleier

Medisinsk overvåkning og intensivavdeling, Sykehuset i Østfold,

Ann-Chatrin Linqvist Leonardsen

Førsteamanuensis

Sykehuset Østfold og Høgskolen i Østfold

ARDS mageleie Oksygen Intensiv

\section{Hovedbudskap}

Pasienter med Acute Respiratory Distress Syndrome (ARDS) er kritisk syke og krever nøye overvåkning i intensivavdeling. Mageleie kan være krevende behandling. Intensivsykepleiere/sykepleiere har behov for solid kompetanse for å ivareta en krevende og kompleks pasientgruppe som dette. 


\section{Innledning}

Respiratorbehandling i mageleie har blitt benyttet i mange år for å bedre oksygenering hos pasienter med ARDS. Studier der man har sammenliknet pasienter i rygg- versus mageleie, har antydet positive fysiologiske effekter og redusert mortalitet hos pasienter med alvorlig grad av ARDS (1). Det er viktig at intensivsykepleieren forstår både den kliniske og praktiske dimensjonen ved denne intervensjonen. Det kan være en krevende oppgave for intensivsykepleieren å observere og vurdere pasienter i mageleie (2). Intensivsykepleierens kunnskaper, erfaring, ferdigheter og holdninger er faktorer som kan påvirke pasientbehandlingen.

\section{ARDS}

Graden av hypoksemi kan beskrives som forholdet mellom $\mathrm{PaO} 2$ og FiO2 (oksygenratio) (3). Oksygenratio gjelder for pasienter som får non-invasiv- (NIV) eller invasiv ventilasjon, og med PEEP > $5 \mathrm{~cm} \mathrm{H} 2 \mathrm{O}$ (4). Alvorlighetsgraden av ARDS klassifiseres etter graden av oksygeneringssvikt etter Berlindefinisjonen fra 2012 (3):

- $\quad$ Mild ARDS: Oksygenratio 26,6-40 kPa (200-300 $\mathrm{mmHg}$ )

- $\quad$ Moderat ARDS: Oksygenratio 13,3-26,6 (100-200 $\mathrm{mmHg}$ )

- $\quad$ Alvorlig ARDS: Oksygenratio $<13,3 \mathrm{kPa}(<100 \mathrm{mmHg})$

ARDS er en akutt inflammatorisk prosess i lungene som forårsaker alvorlig hypoksisk respirasjonssvikt. Den kan utvikle seg på bakgrunn av underliggende alvorlig sykdom eller skade. Alvorlig pneumoni, aspirasjon av mageinnhold og massiv vevsskade i lungene er direkte årsaker til ARDS. Alvorlig sepsis og store traumer med massive vevsskader andre steder i kroppen er en vanlig indirekte årsak (5). Ulike prosesser gir $\varnothing \mathrm{kt}$ lungekapillærpermeabilitet og væskeutsiving til interstitiet og alveolene. 
Den $\varnothing$ kte væskemengden i alveolene reduserer og inaktiverer surfaktant. Dette vil føre til atelektaser, shunting og forstyrrelser i gassutveksling med nedsatt oksygeninnhold i arterielt blod. Senere i forløpet vil det oppstå mikrotrombosering og okklusjon av små kar i lungekretsløpet, med pulmonal hypertensjon som følge. ARDS medfører betydelig reduksjon av compliance i det affiserte lungevevet og nedsatt luftholdighet i alveolene. Den tunge og ødematøse lungen som trykker på disse områdene gjør at områdene blir stive, tunge og vanskelig å ventilere. Samtidig vil buktrykket komprimere de basale delene av lungen ytterligere. Manglende surfactant og inflammasjon gjør at lungevevet blir fibrotisk og mindre elastisk, noe som gir ytterligere forverring av compliance og gassutveksling (4, $5,7)$.

\section{Kliniske symptomer}

Initialt sees først og fremst hypoksemi med lav pO2 og SaO2. Det vil være begrenset effekt av oksygentilførsel grunnet shunting av blod forbi lufttomt lungevev. Tungpustenhet og rask respirasjonsfrekvens med bruk av hjelpemuskulatur er typiske symptomer. Initialt vil pasienten hyperventilere på grunn av oksygeneringssvikt. pCO2 kan være lav, men senere i forløpet sees stigende pCO2 grunnet hypoventilasjon, $\varnothing \mathrm{kt}$ patologisk dødrom i lungene og utmattelse $(4,5)$. På røntgen thorax sees diffuse og flekkvise bilaterale infiltrater, ofte kalt hvit lunge (8).

\section{Sykdomsutvikling og prognose}

ARDS utvikles som regel innen en uke etter den utløsende sykdommen eller skaden. Den akutte fasen kjennetegnes av interstitielt og alveolært $\varnothing \mathrm{dem}$ og inflammasjon. I tidlig fase av ARDS - innen to til tre døgn - kan lungekollapsen være reversibel. Hvis lungesvikten har vart i to til tre uker, har lungevevet blitt så stivt og fibrotisk at det ikke lar seg gjenåpne. Pasienter kan utvikle lungefibrose og kronisk respirasjonssvikt. I mer enn 50 prosent av tilfellene bedrer lungefunksjonen seg etter dager og uker med respiratorbehandling, og lungefunksjonen blir tilnærmet normal. Prognosen ved ARDS er alvorlig, med mortalitet angitt til 30-50 prosent (4).

\section{Lungeprotektiv ventilasjon}


Ved alvorlig ARDS tilstrebes ventilasjon med lave tidalvolum og inspirasjonstrykk < $30 \mathrm{~cm} \mathrm{H2O}$, for å unngå

ventilatorinduserte lungeskader. Med høy PEEP og forlenget inspirasjonsfase kan tidalvolumet leveres med lavere luftveistrykk. Tidalvolumet bør holdes så lav som mulig, 4-6 $\mathrm{ml} / \mathrm{kg}$ idealvekt (1). Det bør aksepteres en stigning av pCO2 og fall i pH, såkalt permissiv hyperkapni og respiratorisk acidose $(3,4)$. En fors $\varnothing$ ker å holde $\mathrm{FiO} 2$ under o,6 med $\mathrm{SaO}_{2}$ 88-90 prosent, relatert til oksygenets toksiske virkninger på alveoler og lungevev. Bruk av PEEP og forlenget inspirasjonstid kan også redusere oksygenbehovet. PEEP brukes for å forhindre atelektaser, rekruttere alveoler og bedre gassutvekslingen (5).

\section{$\equiv$ «De positive fysiologiske effektene gir mindre risiko for lungeskader med ventilasjon i mageleie.»}

Lungeprotektiv ventilasjon i mageleie bedrer rekrutteringen av kollapsete alveoler. Med lavere FiO2 og luftveistrykk, reduseres risikoen for ventilatorinduserte lungeskader (9). De positive fysiologiske effektene gir mindre risiko for lungeskader med ventilasjon i mageleie. Bakgrunnen er en jevnere fordeling av trykk og volum (10). Fordelingen av det transpulmonale trykket blir mer likt fordelt i mageleie enn i ryggleie.

\section{Mageleie}

Pasienter med tiltakende respirasjonssvikt og økende oksygenbehov samt høye PEEP verdier kan ha nytte av mageleie. Det transpulmonale trykket reduseres og jevnes ut. Risikoen for ventilatorinduserte lungeskader med alveolær overdistensjon, barotraume og atelektaser reduseres. Behovet for høy FiO2, høyt inspirasjonstrykk og PEEP kan reduseres $(11,12)$.

Schwartz et al. (12) mener at pasienter med refraktær hypoksemi og alvorlig ARDS, til tross for lunge protektive ventilasjon, kan ha effekt av mageleie. Harcombe (8) hevder at mageleie blir benyttet som en siste løsning når ikke annen behandling fører til bedring i pasientens tilstand.

\section{Ventilasjon og perfusjon (V/Q-forhold)}


Hos pasienter med ARDS i ryggleie er det et misforhold mellom ventilasjon og perfusjon, da perfusjonen er størst i områder hvor det er atelektaser. Mageleie medfører en mer homogen fordeling av perfusjon og ventilasjon $(6,12)$. Ved vending i mageleie oppheves kompresjonen og atelektaser basalt og dorsalt vil lettere $1 \varnothing$ ses opp. Ødemer endres og oksygeneringen i dårlig ventilerte alveolområder $\varnothing$ ker. Dette kan gjøre det lettere å ventilere pasienten. Forholdet mellom ventilasjon og perfusjon bedres $(3,6)$. Ved kontrollert overtrykksventilasjon endres fordelingen av ventilasjonsgassen og forholdet mellom ventilasjon og perfusjon. Mer frisk gass går til de øvre delene av lungene enn til de nedre. Apikale deler av lungene blir best ventilert, mens basale deler best perfundert, og det blir et misforhold mellom ventilasjon og perfusjon, såkalt V/Q mismatch.

\section{Fysiologiske effekter}

Studier har vist at ventilasjon av pasienter med ARDS i mageleie kan gi økning i $\mathrm{PaO} 2$ med reduksjon i FiO2 etter 30 minutter. Særlig pasienter med indirekte årsak til respirasjonssvikten, drar fordel av denne behandlingen (12). Mageleie optimaliserer alveolerekrutteringen, bedrer ventilasjon og perfusjon av dorsale lungeavsnitt og kan gi redusert trykk på thorax (1). Wright\& Flynn (2) nevner videre $\emptyset \mathrm{kt}$ funksjonell residual kapasitet (FRC), bedret gassutveksling, endring i bevegelse av diafragma, sekretmobilisering samt forebygging av ventilator assosiert pneumoni (VAP) og atelektaser. Studier viser til bedring i oksygenratio hos pasienter med alvorlig ARDS som blir behandlet med mageleie over lengre perioder av gangen. Overvektige vil også kunne profittere på å bli snudd over på magen, da trykk fra abdomen minsker og bedrer ventilasjonen. Videre er det funnet bedring av oksygenering gjennom $\varnothing \mathrm{kt}$ sekretmobilisering og reduksjon av ekstravaskulært lungevann (2).

\section{Tidspunkt og varighet}

Fibrose gjør lungene tunge og mindre ettergivelige. Pasienter med ARDS bør legges tidlig i mageleie, før den fibroproliferative fasen (13). Hos pasienter med alvorlig ARDS er det viktig med tidlig igangsettelse av behandlingen, fordi kollapsete lungeavsnitt er enklest å åpne under den akutte eksudative fasen $(1,12)$.

Gevinsten er størst ved mageleie tidlig i forløpet av alvorlig ARDS. Drahnak \& Custer (9) fant at gevinsten er størst ved mageleie innen 72 timer og opp til 20 timer daglig. 


\section{Risikofaktorer og komplikasjoner}

Hypotensjon og arytmier, fall i oksygenmetning, luftveisobstruksjon, oppkast og brekninger er komplikasjoner med overhyppighet i mageleie så vel som dislokasjon av tuben og invasive katetre $(2,12)$. Ødemer i ansiktet kan også oppstå $(9,12,15)$. Vasopressor som reduserer den perifere sirkulasjon $\varnothing$ ker faren for trykksår. Bryster og mannlige genitalia er utsatt for trykk. Hjertestans er påvist å ha høyere forekomst ved ryggleie enn i mageleie. Spinale skader er en absolutt kontraindikasjon ved mageleie. Thorax og abdominal kirurgi er relativt kontraindisert, og det samme er alvorlige arytmier med hemodynamisk påvirkning, da det vanskeliggjør tilgang ved hjerte-lunge-redning. Andre faktorer er forhøyet intrakranielt trykk, ustabile frakturer, massiv hemoptyse, nyoppstått DVT og alvorlig hypotensjon (12).

\section{Mortalitet}

PROSEVA-studien sammenliknet mageleie versus ryggleie hos pasienter med alvorlig ARDS tidlig i forløpet. 466 pasienter ble inkludert i studien, 229 i ryggleie-gruppen og 237 i mageleie-gruppen. Alle fikk mekanisk ventilasjon med en lunge protektivstrategi. Mortaliteten var signifikant lavere i mageleie-gruppen enn ryggleie-gruppen etter 28 dager, og etter 90 dager (14).

I PS II-studien inkluderte man 342 pasienter med moderat og alvorlig ARDS. 168 pasienter ble lagt i mageleie og $174 \mathrm{i}$ ryggleie. Alle ble mekanisk ventilert med en lungeprotektiv strategi. Det ble ikke funnet noen signifikant bedret overlevelse i mageleie-gruppen kontra ryggleie-gruppen.

\section{«I seks av studiene som benyttet en lungeprotektiv ventilasjon med redusert tidalvolum i kombinasjon med mageleie, var mortaliteten signifikant lavere.»}

En systematisk oversikt og metaanalyse av 11 studier fra 2001-2013 sammenliknet rygg- og mageleie. I seks av studiene som benyttet en lungeprotektiv ventilasjon med redusert tidalvolum i kombinasjon med mageleie, var mortaliteten signifikant lavere.

\section{Sykepleieres observasjoner og vurderinger under og etter snuing}

- Sikre luftveier og endotrakealtuben. Anestesilege skal være til stede og ta ansvar for luftveier, og det anbefales å teipe tuben godt før prosedyren. 
Forsikre seg om at tungen er inne i munnen. Ved hoven tunge kan det benyttes svelgtube. Lukket sug anbefales da mange pasienter har behov for høy PEEP.

- Følge $\mathrm{SaO} 2$, respirasjonsfrekvens, ta arteriell blodgass 30 minutter etter plassering i mageleie. Notér respiratorinnstillinger, oksygenratio og vitale parametere før, under og etter prosedyren for å vurdere responsen på behandlingen. Kontinuerlig observere trender og endringer i luftveistrykk og tidalvolum.

- Observere og vurdere væskebalanse. Sikre vevsperfusjon og samtidig forebygge hypervolemi.

- Sikre at intravenøse og arterielle innganger er fri og fungerer.

- Observere bevissthetsnivå. Sikre pasienten optimal sedasjon og analgetika, samt muskelrelaksantia for å senke oksygenbehovet. Bolus doser med sedativa og analgetika før leieendring blir anbefalt.

- Observere og forebygge aspirasjon. Det anbefales å stoppe enteral ernæring minst en time før snuing.

- Observere og forebygge aspirasjon relatert til økt slimproduksjon. Suges jevnlig i tube, munn og svelg.

- Endre stilling på hode og ekstremiteter hver andre time.

- Observere Øyne. Øyestell med jevnlig fukting og tildekking for å forebygge uttørking og infeksjoner.

- Observere hud og forebygge trykksår. Avlaste med puter på trykkutsatte områder og passe på at ledninger og slanger ikke blir avklemt eller lager trykk. Legge slanger og ledninger oppover mot hodet og påse at de er tilstrekkelig lange.

- Forebygge trykk fra abdomen, slik at diafragma kan bevege seg fritt.

\section{Kunnskap, holdninger og ressurser}

Harcombe beskriver en motvilje mot å snu kritisk syke pasienter, til tross for at litteratur viser til at mageleie anbefales tidlig ved ARDS. Hun antar at noe av denne motviljen kan være mangel på kunnskap. Hun mener at både teoretisk og praktisk undervisning om ARDS og fysiologiske effekter i mageleie, kan øke intensivsykepleierens kompetanse (8). Dette støttes også av annen forskning, som også påpeker viktigheten av etablerte retningslinjer og prosedyrer $(2,9,15,16)$. 
Det kreves tilstrekkelig med ressurser hos dem som skal delta i behandlingen. Intensivsykepleieren har primært et ansvar for å forberede og gjennomføre forflytning, og kontinuerlig observere og vurdere pasienten. Den praktiske gjennomføringen av prosedyren er krevende, og det er behov for et tverrfaglig team (14). Avdelingens kultur er også nevnt som en faktor for om behandling i mageleie blir gjennomført (16).

\section{Konklusjon}

Kompetanse, kjennskap til prosedyrer og komplikasjoner, samt tilstrekkelige ressurser, trekkes frem for å kunne observere og vurdere pasienter i mageleie. De må kjenne til patofysiologien til ARDS og fysiologiske effekter av mageleie. I tillegg trengs kjennskap til hvilke pasienter som kan ha fordel av denne behandlingen, tidspunkt for og varighet av mageleie, samt observasjoner og forventete komplikasjoner. Ved å holde seg oppdatert innen forskning på pasienter med ARDS som behandles i mageleie, kan intensivsykepleiere/sykepleiere på et bedre grunnlag identifisere de pasienter som kan ha positiv effekt av behandlingen.

\section{Referanser}

1. Guèrin C. Prone ventilation in acute respiratory distress syndrome. EUR Resp Review 2014; 23:249-57

2. Wright AD, Flynn M. Using the prone position for ventilated patients with respiratory failure: a review. Nurs Crit Care 2011;16(1):19-27.

3. Giæver P. Lungesykdommer. Oslo: Universitetsforlaget; 2011.

4. Ingvaldsen BI. Væske, elektrolytter, blodgasser og infusjonsterapi. Oslo: Oslo universitetssykehus Ullevål; 2014.

5. Bakkelund J, Thorsen BH. Respirasjonssvikt. I:

Gulbrandsen T, Stubberud DG. red., Intensivsykepleie. Oslo: Cappelen Damm; 2015.

6. Opdahl H. Akutt respirasjonssvikt ved alvorlig sykdom og skade. Tidsskr nor legefor 2010;130(2):154-57. 
8. Harcombe C. Nursing patients with ARDS in the prone position. Nurs Stand 2014;18(19):33-9.

9. Drahnak DM, Custer N. Prone Positioning of Patients With Acute Respiratory Distress Syndrome. Crit Care Nurs 2015;35(6):29-37.

10. Taccone P, Pesenti A, Latini R, Polli F, Vagginelli F, Mietto C, Caspani L, et al. (Prone-Supine II Study Group);2009. Prone Positioning in PatientsWith Moderate and Severe Acute Respiratory Distress Syndrome. J Am Med Assoc 2009;302(18):1977-84.

11. Mure M, Larsson A, Fredèn F, Lindèn V. Adjuvant behandling vid andningssvikt. I Larsson A, Rubertsson S (red.). Intensivvård. Stockholm: Liber; 2012.

12. Schwartz D, Malhotra A, Kacmarek RM. Prone ventilation. UpToDate; 2016.

13. Léonet S, Fontaine C, Moraine JJ, Vincent JL. Prone positioning in acute respiratory failure: Survey of Belgian ICU nurses. Int Car Med 2002; 5(28):576-80.

14. Guérin C, Reignier J, Richard JC, Beuret P, Gacouin A, Boulain T, Mercier E, et al. (PROSEVA Study Group). Prone Position in Severe Acute Respiratory Distress Syndrome. N Engl J Med 2013;368(23):2159-68.

15. McCormick J, Blackwood B. Nursing the ARDS patient in the prone position: the experience of qualified ICU nurses. Int Crit Care Nurs 2001;17(6):331-40.

16. Gibson K, Dufault M, Bergeron K. Prone positioning in acute respiratory distress syndrome. Nursing Standard 2015;29(50):34-39. 